\title{
Rapid flash annealing of thermally reactive copolymers in a roll-to-roll process for polymer solar cells
}

Helgesen, Martin; Carlé, Jon Eggert; Andreasen, Birgitta; Hösel, Markus; Norrman, Kion; Søndergaard, Roar; Krebs, Frederik C

Published in:

Polymer Chemistry

Link to article, DOI:

10.1039/C2PY20429K

Publication date:

2012

Document Version

Peer reviewed version

Link back to DTU Orbit

Citation $(A P A)$ :

Helgesen, M., Carlé, J. E., Andreasen, B., Hösel, M., Norrman, K., Søndergaard, R., \& Krebs, F. C. (2012).

Rapid flash annealing of thermally reactive copolymers in a roll-to-roll process for polymer solar cells. Polymer Chemistry, 3(9), 2649-2655. https://doi.org/10.1039/C2PY20429K

\section{General rights}

Copyright and moral rights for the publications made accessible in the public portal are retained by the authors and/or other copyright owners and it is a condition of accessing publications that users recognise and abide by the legal requirements associated with these rights.

- Users may download and print one copy of any publication from the public portal for the purpose of private study or research.

- You may not further distribute the material or use it for any profit-making activity or commercial gain

- You may freely distribute the URL identifying the publication in the public portal 


\section{RSCPublishing}

DTU Library

Technical Information

\section{DT}

RSC I ChemSpider I Feedlback

Login I Register

- $\underline{\text { Journals }}$

- $\underline{\text { Books }}$

- $\underline{\text { Alerts }}$

- Others

- Help

Full Text Enter your search phrase

Advanced Search

$\underline{\text { Home }}>\underline{\text { Journals }}>$ Polymer Chemistry $>$ Rapid flash annealing o...

Authors \& Referees I Librarians

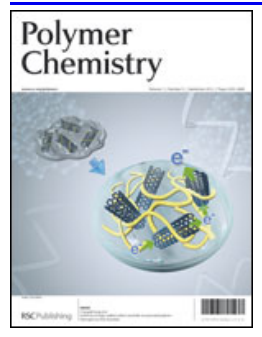

\section{Polymer Chemistry}

Issue 9,2012 More about this Journal

Editorial Board

$\underline{\text { Submit an Article }}$

Follow Journal

\section{Supplementary Info}

Journal Home I RSC Journals

- Supplementary

information

PDF (702K)

\section{Articles By}

- $\square$ Martin Helgesen

- $\square$ Jon Eggert Carlé

- $\square$ Birgitta Andreasen

- $\square$ Markus Hösel

- $\square$ Kion Norrman

- $\square$ Roar Søndergaard

- $\square$ Frederik C. Krebs 
(C) Royal Society of Chemistry 2012

Terms \& Conditions IPrivacy IAccessibilitylACAP Enabled
Also from the RSC

Photo-initiated

Quantum Molecular

Dynamics:

Faraday Discussion 163

15-17 April 2013,

University of Nottingham, UK

\section{燥}

Download

the Chemspider '

app for free

Advertisements

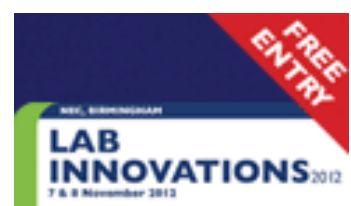

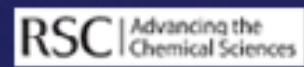

Conference

programme

organised by

the Royal Society

of Chemistry

CeasyFairs

sasyfairs.com/labinnovation:

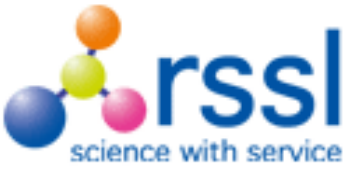

Paper

$\underline{\text { Previous Article I Next Article }}$

\section{Rapid flash annealing of thermally reactive copolymers in a roll-to-roll process for polymer solar cells}

Martin Helgesen, Jon Eggert Carlé, Birgitta Andreasen, Markus Hösel, Kion

Norrman , Roar Søndergaard and Frederik C. Krebs

Polym. Chem., 2012,3, 2649-2655

DOI: $10.1039 / \mathrm{C} 2 \mathrm{PY} 20429 \mathrm{~K}$

Received 18 Jun 2012, Accepted 02 Jul 2012 
First published on the web 04 Jul 2012

Share ० $\quad|||| \mid$

- $\mathrm{PDF}$

- 5 ich HTML

- $\quad$ Buy PDF (£34)

\section{Download Citation}

BibTex

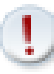

Please choose one of the options provided in the log in section to gain access to this content:

\section{Abstract Cited by Related Content}

Light induced thermocleaving of a thermally reactive copolymer based on dithienylthiazolo[5,4- $d$ ]thiazole (DTZ) and silolodithiophene (SDT) in contact with the heat sensitive substrate the heat sensitive substrate polyethyleneterphthalate (PET) was effectively demonstrated with the use of high intensity pulsed light, delivered by a commercial photonic sintering system. Thermally labile ester groups are positioned on the DTZ unit of the copolymer that can be eliminated thermally for enhanced photochemical stability and advantages in terms of processing (solubility/insolubility switching). The photonic sintering system was successfully implemented in a full roll-to-roll process on flexible PET substrates and large-area polymer solar cell modules were prepared by solution processing of five layers under ambient conditions using the photonic sintering system for thermocleaving of the active layer. The PET foil did not show any deformation after exposure to the high intensity light only leaving the insoluble thermocleaved active layer. The active layer remained planar after light exposure thereby allowing the coating of supplementary material on top.

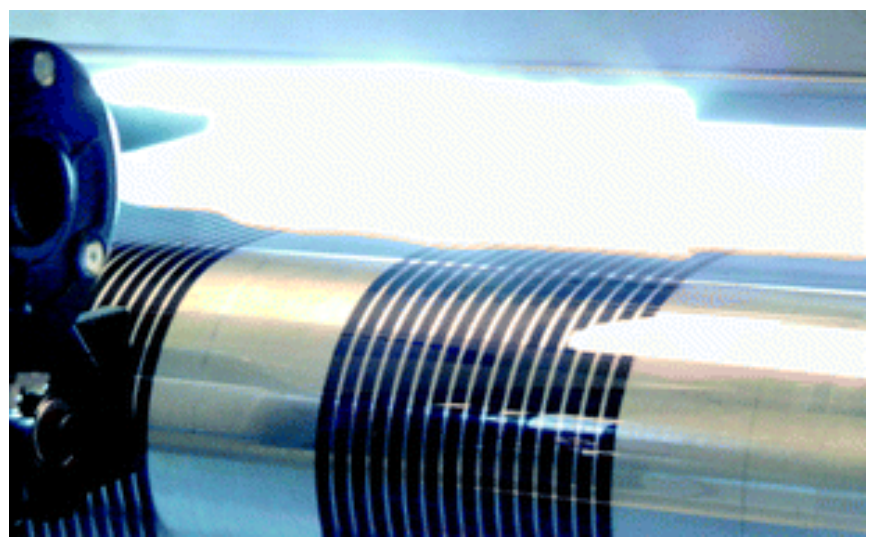

\section{Log in (Subscriber Access)}

\section{Login via Athens or your}

home institution 
02.08.12 Rapid flash annealing of thermally reactive copolymers in a roll-to-roll process for polymer solar cell...

Login with your subscriber

username and password

Username*

Password*

Ask your librarian to arrange site-wide access. 